\title{
IMPLICATIONS OF GOVERNMENT LEGAL SUBJECT STATUS AS ONE OF THE CAUSES OF TAX DISPUTES ON PRODUCTION SHARING CONTRACTS FOR THE OIL AND GAS INDUSTRY IN INDONESIA
}

\author{
Mulyo Basuki \\ Faculty of Law, University of Indonesia, Depok, Indonesia \\ Email: Mbasuki.bkp@gmailcom
}

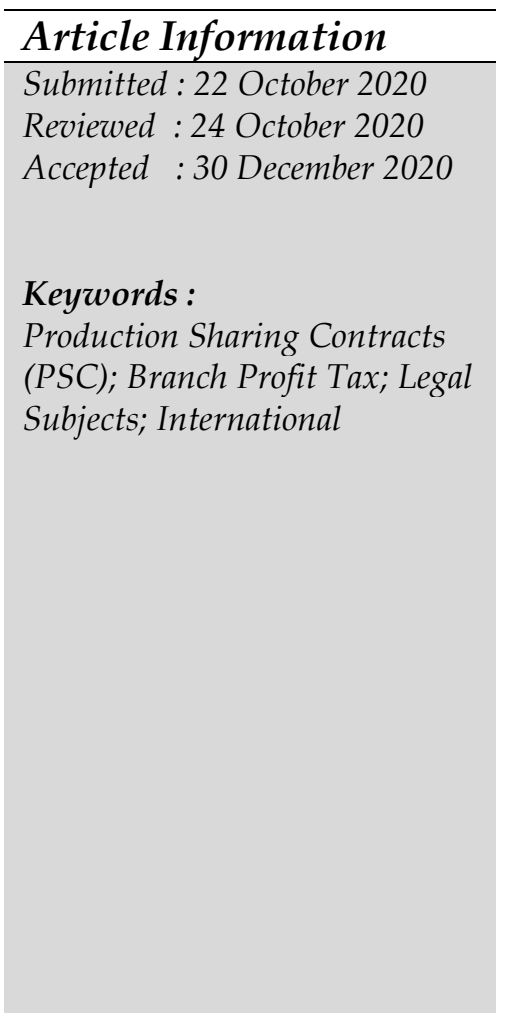

\begin{abstract}
Supreme Court Decision Number 2424/B/PK/Pjk/2020 states that the PSC (Production Sharing Contract) is a Government to Business ("G to B") agreement that applies domestic taxes. Therefore, in tax disputes over Branch Profit Tax (BPT) between a Permanent Establishment Taxpayer (BUT) and the DirectorGeneral of Taxes, the Supreme Court's decision uses a 20\% domestic tax rate instead of $10 \%$ in accordance with the Tax Treaty. This study elaborates how the Government's position in the production sharing contract with the private sector or PE is related to Indonesian and international tax law. The main issues raised are the Government's position as a legal subject in the PSC agreement and the process associated with regulating BPT in international taxation. This is a library study with the juridicalnormative approach method. The results showed that the Government acts as a subject of civil law in the PSC agreement. However, in the PSC contract, the relationship between the state and the private sector or PE (BUT) in natural resource management must be carried out using a public relationship by giving concessions or permits full of state control and power. For instance, the Indonesian tax law does not apply when there is a tax treaty. The Taxation Law in Indonesia cannot unilaterally interpret taxes on BPT based on Indonesian domestic provisions.
\end{abstract}

\section{Introduction}

The Government's status in taking legal actions needs to be clarified to avoid tax implications. However, as a public institution, it is liable to take civil legal actions. Furthermore, the Government as a legal entity is found in Article $1653 \mathrm{BW}$, which stated that the public power holds a recognized legal entity.

Article 33 of the 1945 Constitution stipulates that the main assets of a nation are controlled by the state and used for the community's greatest prosperity. According to Law Number 5 of 1960 concerning Basic Agrarian Regulations stated that the implementing organization and the authority or task of controlling the state are vested in the Indonesian Government. Consequently, this provision also applies to the Oil and Gas sector because it is a nonrenewable natural resource. Oil and natural gas plays a strategic role in the 
lives of Indonesians both as a domestic energy source and a significant source of state revenue. The history of petroleum regulation started with the issuance of Law Number 8 of 1971 concerning State Oil and Gas Mining Companies. Law Number 8 of 1971, in which authorized PERTAMINA to manage these natural resources, starting from exploration, exploitation, refining, and processing, as well as transportation and sales. Article 12 paragraph (1) of Law No. 8 of 1971 stated that companies tend to cooperate with other parties in the form of "Production Sharing Contracts." Therefore, in the explanatory section, it was noted that there is a need to seek the most favorable conditions to the state. The role of PERTAMINA, in particular, was later revoked with the enactment of Law Number 22 of 2001 concerning Oil and Natural Gas.

From January to December 2011, there was a tax dispute between the Directorate General of Taxes (DGT) and the taxpayers that signed the Production Sharing Contract with PERTAMINA. This dispute started when the DGT made certain corrections, including applying a rate of $20 \%$ on Income Tax $(\mathrm{PPh})$ as stipulated in Article 26 paragraph (4) concerning Branch Profit Tax (BPT) or Interest and Royalty Tax (PBDR) transactions. Taxpayers in their appeal at the Tax Court stated that they were entitled to use the Double Taxation Avoidance Agreement (Tax Treaty) between Indonesia and the UK, and no provision in the Production Sharing Contract prohibits them from using the rates in the Tax Treaty. According to the Tax Court Judges Council, the taxpayers won the dispute on the understanding that the DGT correction is inappropriate and was canceled. Furthermore, the tax dispute ended in the Supreme Court.

The Supreme Court Decision Number 2424/B/PK/Pjk/2020, in its legal considerations, assumes that the Production Sharing Contract (PSC) is a Government to Business ("G to B") agreement, which involves domestic tax. On the contrary, the Tax Treaty is a Government agreement that applies international tax law. Production Sharing Contract (PSC) is a treaty or agreement with joint ventures regulating production sharing in the mining sector. Meanwhile, the Tax Treaty regulates the distribution of taxation in connection with the emergence of rights and obligations inherent in agreements originating from business profit activities with international jurisdiction, therefore taxpayers have no choice and need to adopt the in dubio contra fisco principle.

This is because there are two lex specialists on the Income Tax Law, namely.

(a) Tax Treaty on the power of Article 32A, and 
(b) PSC on the power of Article 33A (4), are stipulated in the Income Tax Law and based on the principle of lex consumen derogat legi consumte, PSC provisions dominates taxpayers' taxation rather than Tax Treaty. Therefore taxpayers are unable to obtain tax facilities and a $20 \%$ BPT rate in accordance with the Income Tax Law. This enactment also safeguards the distribution of oil and gas revenues based on the PSC contract in connection with the sharing principle.

This study considers the fact that there are legal issues related to regulatory obscurity. Besides, it also tries to determine the truth that PSC $(\mathrm{KBH})$ is a Government to Business ("G to B") agreement that applies domestic tax, while taxation using Tax Treaty does not have to be applied because taxpayers have no choice other than applying the Indonesian domestic law. The author considers the contract or agreement as a civil action. The implementation of the proportionality principle in every contract or agreement needs to be conducted in good faith. Furthermore, it is also necessary to review the Constitutional Court Decision Number 36/PUU-X/2012, which mandates that Article 1 number 23, Article 4 paragraph (3), Article 41 paragraph (2), Articles 44, and 45, Article 48 paragraph (1), Article 59 letter a, Articles 61, and 63 of Law Number 22 of 2001 regarding Oil and Natural Gas (State Gazette of Indonesia of 2001 Number 136, Additional State Gazette of Indonesia Number 4152) contradicts the 1945 Constitution and has no legal binding force. Based on the Presidential Regulation No.9 of 2013, subsequent developments such as a special work unit were formed to implement upstream oil and gas business activities (SKK Migas / Special Task Force for Upstream Oil and Gas Business Activities).

Interestingly, the Government's simultaneous position as a legal entity and subject in the Oil and Gas Production Sharing Contract Agreement in Indonesia needs to be examined. Secondly, the arrangement of Branch Profit Tax (BPT) in the Tax Treaty.

\section{Research Methods}

The normative-juridical approach was adopted in this research. This approach discusses doctrines or principles in legal science (Ali, 2015). Furthermore, a study related to the level of legal synchronization is included in this research method (Ali, 2015: 24). The primary legal materials studied were the 1945 Constitution, the Civil Code, the Basic Agrarian Law, Law Number 8 of 1971 concerning State Oil and Gas Mining Companies which were subsequently repealed by Law Number 22 of 2001, the Income Tax Law, the Double Tax Avoidance Agreement (P3) or Tax Treaty between Indonesia and 
the UK, and the United States of America, as well as Presidential Regulations and Constitutional Court Decisions. In addition, the secondary legal materials studied include books related to agreements, contracts, legal subjects, and also petroleum. Meanwhile, the tertiary legal material studied was the Complete Edition of the Legal Dictionary, English-Indonesian-English.

\section{Research Results and Discussion}

\section{A. The position of the Government as a legal entity as well as a legal subject in the Oil and Gas Production Sharing Contract Agreement in Indonesia}

A person or an entity is a legal subject relevant to the nature of civilization. Subekti, in the book entitled Pokok-Pokok Hukum Perdata (The Principles of Civil Law), stated that in law, the person is the bearer of rights or the subject (Subekti, 2010: 19). According to Rochmat Soemitro, a rechtperson is an entity that has assets, rights, and obligations (Soemitro, 1993: 10). Based on this opinion, it is clear that a legal entity is always related to assets in the realm of private law. However, it was greatly discovered that legal entities in normative law are regarded as legal subjects (Hadjon \& Djamiati, 2017: 4).

Moreover, as a legal entity (legal person, rechpersoon), state administrative agencies or officials play the role of actors in binding various civil agreements. Legal actions carried out by state administrative agencies or officials are not regulated based on public law. On the contrary, civil law (privaatrect), as is usually the case underlies certain lawful acts committed by a citizen or legal entity (Hadjon, 2015). Public legal entities are also used to establish a civil legal entity such as Limited Liability Companies, Cooperatives, and Foundations (Chidir, Ali, 2005: 63).

The establishment of such a legal entity is regulated by Article 1653 BW, therefore according to Chidir Ali, there are 3 (three) forms, namely

(a) Legal entities held by public interests (government or state), such as provinces, autonomous regions, regencies, etc

(b) A legal entity recognized by the public authority,

(c) A permissible legal entity, established in accordance with a specific purpose, which is not against the law or morality.

Of the three types of legal entities mentioned, the third form is also known as a legal entity with civil construction. Furthermore, the Government as a legal entity also carries out civil actions as stipulated in article 1654 BW, which stated that 
"All legally established entities, as well as private subjects, have the right to carry out civil acts, without prejudice to laws that, limit or subject them to certain procedures."

In other words, assuming the Government is one of the parties involved in a contract, their position in civil law relations is similar to the other private legal subjects, namely people or legal entities. Legal actions carried out by state administrative agencies or officials are not regulated based on public law. Conversely, civil law (privaatrect), as is usually the case underlies the lawful acts committed by a citizen or legal entity (Hadjon, et all, 2015: 161).

The Government is not treated specially during civil disputes, rather it has the same position as a person or civil legal entity in a general court. Apparently, as a legal entity (legal person, rechpersoon), the state administrative agencies or officials act as civil actors and get involved in various civil agreements. The public legal entities also tend to establish Limited Liability Companies, including Cooperatives and Foundations (Chaidir, Ali, 2005)

Besides, the term contract is also used in place of agreement. Grammatically, this term is an English word, which means an agreement or approval, binding one or more persons (Legal Dictionary, 1977). In addition, agreement and contract have similar meanings, which is an act to mutually bind parties into a legal relationship. The term contract is used more often in business practice. Moreover, since it is rare for entrepreneurs to run their businesses carelessly, contracts are usually in written forms, therefore it is also referred to as written agreement.

A contract is a legal relationship between two or more people regarding an asset, where one party is entitled to an achievement, and the other is obliged to fulfill that accomplishment (Badrulzaman, 2015: 9). The existence of an agreement commonly known as a contract, is inseperable from the fulfillment of conditions regarding its validity as stated in Article 1320 of the Civil Code, which includes the following

1. Agree to the terms of those that bind themselves,

2. The ability to make an engagement,

3. A certain thing,

4. A lawful cause.

Freedom of contract and the pacta sunt servanda principle causes injustice. Therefore, those that have a stronger bargaining position tend to control the weaker party (Khairandy, 2017: 2). Khairandy cited The Doctrine of Good Faith in German Contract Law by Jack Beatson and Daniel Friedmand, which stated that the development of the good faith doctrine is a result of court 
work rather than a legislation that is developed on a case-by-case basis. The entire process needs to be performed in good faith, from the pre-contract phase, where the parties start negotiating until an agreement is reached at the contract implementation stage (Khairandy, 2017: 8)

Freedom of contract, which is the "spirit" and "breath" of an agreement, implicitly shows that the parties are assumed to have an equal position. (Hernoko, 2014: 2). Conversely, this agreement is based on the freedom of contract principle. Article 1319 of the Civil Code stated that "All agreements, whether or not, they have a special name, are subject to the general regulations contained in these chapters and some other literatures."

The understanding that the Government in contracting with the private sector acts as a subject of civil law also involves the need to consider special matters, including those related to natural resources. In its legal consideration, the Constitutional Court Decision Number 36/PUU-X/2012 stated that the Cooperation Contract (KKS) in oil and gas business activities is a contract with a civilization nature and subject to civil law. The Oil and Gas Cooperation Contract does not fulfill the criteria that cause it to be referred to as an international agreement in Article 11 paragraph (2) of the 1945 Constitution. Therefore it does not require the Parliament's approval. However, the relationship between the state and private sector regarding the management of natural resources need not be a civil one, rather it is a public affair involving the granting of concessions or permits that are fully under the control and power of the state. Civil contracts degrade a country's sovereignty over natural resources, such as oil and gas. Based on these considerations, and the Court, the relationship between the state and natural resources is in the form of a Cooperation Contract between the Oil and Gas Implementing Agency, regarded as a State-Owned Legal Entity in a Government Party. In addition, the Government is represented in Business Agencies or Permanent Establishments as regulated in Law Number 22 of 2001, which stated that this is contrary to the principle of state control referred to by the constitution. To avoid this relationship, the state tends to form or appoint an SOE that is granted the concession to manage oil and gas in Indonesia's legal mining areas. Therefore, the SOE is the individual that enters into a Cooperation Contract with a Business Entity or Permanent Establishment (Constitution Court Decision Number 36/PUU-X/2012). Furthermore, to fill the legal vacuum due to the absence of an Oil and Gas Implementing Agency, the Court needs to emphasize the state organization that performs the functions and duties of the Oil and Gas Implementing Agency until the new regulations are formed. According to the Court, these functions and duties need to be carried out by the Government, 
although in this case, the authorized Ministry is responsible for the oil and gas sector. However, as reported in previous studies, the Constitutional Court's decision does not specifically evaluate the taxation rights of a transaction.

\section{B. Regulation of Branch Profit Tax (BPT)}

The term tax subject is common in taxation. It is classified into Domestic and Foreign Tax Subjects (Sumitro, 1986: 57-59). Domestic Tax Subjects (SPDN) are regarded as taxpayers, supposing they have received or earned income. Conversely, Foreign Tax Subjects (SPLN) are also taxpayers whose income source is obtained from the country or through a permanent establishment. This SPDN includes Oil and Gas Cooperation Contract Contractors (K3S).

The K3S obligation to pay corporate income tax is one of the policies regulated in the PSC. Article 33 A of the Income Tax Law mandates that:

Taxpayers involved in oil and gas businesses, general and other mining activities based on production sharing, or work contracts, as well as mining exploitation cooperation agreements, are still effective regarding when this law was enacted. Therefore the tax is calculated based on the provisions in the production sharing or work contracts and the mining exploitation cooperation agreement.

An example is the Branch Profit Tax ("BPT"). The law regulates that, After deducting tax from a permanent establishment, taxable income is subject to $20 \%$ (twenty percent) unless the income is reinvested in Indonesia. The provisions are further stipulated by or based on the Minister of Finance Regulation (Article 26 of Law Number 36 of 2008 concerning Income Tax. Law). Article 26 paragraph (4) is also related to the Branch Profit Tax ("BPT"). Indonesia's domestic tax code stipulates that the BPT rate is $20 \%$. However, supposing the taxpayer is a resident of a country with a Tax Treaty agreement, the BPT rate is reduced according to the Tax Treaty. The Indonesian Tax Treaty model regarding "dividends" also regulates income tax imposition on after-tax profits obtained from a Permanent Establishment located in the country (Sumitro, 1986: 139). The Indonesian and British Tax Treaty stipulates that the BPT rate is reduced to a maximum of $10 \%$.

The double tax avoidance agreement, otherwise known as the Tax Treaty, is an agreement between two countries regarding their rights to minimize double taxation and tax avoidance efforts. Another term for Tax Treaty is Double Tax Avoidance ("DTA"). Phillip Baker stated that the objectives of the Tax Treaty (Baker, 2013: 3):

Tax treaties offer a range of tax advantages, which countries agree to grant to each other to prevent double taxation and eliminate any barrier that tends to 
affect cross-border trade, investment, movement of persons, etc. Examples of these tax advantages are

a. exemption from tax in either of the countries,

b. reduced withholding taxes on dividends, interest, and royalties, and

c. foreign tax credit or exemption to eliminate double taxation.

Tax Treaty is an agreement between the Indonesian Government and other countries to avoid double taxation and prevent tax evasion. It is an implementation of Article 32 A of the Income Tax Law, which mandates that the Government is authorized to enter into agreements with other countries. International taxation often tends to become complicated because it involves the taxing rights of a country. Dr. P. Verloven Van Th Jamaa, a legal expert from England, defined International Tax Law as all the norms regarding tax collection, including international customs and treaties that limit the sovereignty of a country (Sumitro, 1986: 5). According to Rochmat Soemitro, it is defined, as a tax law, which consists of national principles, derived from treaties between countries as well as / customs that are accepted worldwide, to regulate tax issues and foreign elements, regarding both subject and object. International tax is a term that refers to the foreign aspects of the tax provisions of each country. The international tax provisions of a country regulate two factors which are stated as follows (Darrussalam \& Septriadi, 2017: 1):

a. regulates the taxation of domestic subjects that receives income from outside the country and

b. regulates the taxation of foreign residents that receive income from within the territorial area of a country.

The tax Treaty, an agreement between two sovereign countries, is also part of international treaty law. Therefore, interpretation of the articles in the agreement is based on the procedures regulated in public international treaty law. Furthermore, Klaus Vogel reported that the problem with an interpretation relating to domestic provisions is that assuming the Tax Treaty of the countries involved are different, it leads to double taxation. Consequently, this is certainly contrary to the aims and objectives of the Tax Treaty. Therefore, the terminologies or terms in the Tax Treaty need to prioritize independent interpretation (autonomous) (Vogel, 1977: 208-209). In principle, this is intended to determine the allocation of taxation rights from a transaction between the source country and the domicile nation (Surachmat, 2011: 1). Tax Treaty is a lex specialis agreement based on the provisions of the Income Tax Law (lex 
generalis). This means that Tax Treaty is highly placed than the provisions in domestic law (Surachmat, 2011: 2). Its position in accordance with this provision is a lex specialist for domestic law. Therefore, assuming there is a provision in domestic law that contradicts the one in the Tax Treaty, then it is approved.

The Tax Treaty regulates the tax on profits from a Permanent Establishment or, in another term is regarded as a Branch Profit Tax. Article 10 paragraph (7) in the Indonesian and British Tax Treaty, it is stipulated that:

Notwithstanding the other provisions of this agreement, a company which is resident in a Contracting State, and has a permanent establishment in another, derives profits that are taxed (in addition, the tax are charged on the profits realized from the company which is a resident of the other Contracting State) in accordance with the laws of the other Contracting State however the rate of tax imposed need not exceed $10 \%$ of the profits from the permanent establishment after payment of the income tax on those profits.

Therefore, when the Income Tax Law applies a 20\% BPT, the rate tends to be reduced to a maximum of $10 \%$ in accordance with the provisions of Article 10 paragraph (7) of the Indonesian and English Tax Treaty. This is because the Tax Treaty has a lex specialist position in the Domestic Income Tax Law.

This arrangement is different from the Tax Treaty between Indonesia and the United States which regulates that each party or country needs not to reduce tax payments on BPT (dividends) obtained from the Production Sharing Contract (PSC). Article 11 paragraph (5) stated that The rate of tax referred to in paragraph 4 of this article need not affect any additional tax contained in the production sharing and work contracts (or any other similar contracts) relating to oil and gas or other mineral products negotiated by the Indonesian Government, its instrumentality, relevant State oil company or any other entity thereof with a resident of the United States.

The taxation aspect in the Oil and Gas Industry needs to be regulated better and requires high legal certainty because of the long-term contracts. Fiscal Petroleum expert Daniel Johnston, stated that (Johnston, 1994: 16):

"Government has devised numerous frameworks for extracting economic rent from the petroleum sector. Some are properly balanced, efficient, and cleverly designed. Subsequently, some others are ineffective. The fundamental issue is to determine whether or not exploration and/or development are feasible under the conditions outlined in the fiscal system. The outcome of government efforts are sometimes referred to as fiscal marksmanship-which is either poor or good. Structuring an appropriate fiscal system which is targeted at a variety of unknown future circumstances is almost impossible. The purpose of fiscal 
structuring and taxation is to capture all economic rent. This is consistent with giving the industry a reasonable share of profit, or loss. Conversely, the level of industry profit considered to be fair and reasonable is debatable. The issue of division of profits lies at the heart of contract or license negotiations."

Based on Johnston's opinion, the oil and gas sector's taxation problem is significant because it usually affects a country's national fiscal system. The company (K3S) bears all costs, including exploration and business risks. On the contrary, the Government does not bear the costs and risks. $[x]$ Whereas the upstream Oil and Gas industry has different characteristics. In general, the industry is exposed to a high level of risk as well as requires a long time and large investment to discover Oil and Gas reserves. One of the suggestions to prevent risks, especially that related to tax, implies that the K3S needs to include a stabilization clause in its PSC agreement as proposed by Sornarajah, "the aim of the stabilization clause was to ensure that future changes in the legislation of the host state did not vary the terms of the contract based on which entry was made. (Sornarajah, 2010: 279)

\section{Conclusion}

Based on the aforementioned description, it was concluded that the Government authorized the PERTAMINA (currently to the Special Task Force for Upstream Oil and Gas Business Activities) to make a civil agreement. However, based on legal considerations of the Constitutional Court, specifically in the Special Task Force for Upstream Oil and Gas Business Activities, the relationship between the state and the private sector in natural resource management need not be considered as civil, rather it is a public affair, because it involves the granting of concessions or permits which are fully under the state control and power. However, it is not entirely appropriate to regard the PSC as a Government to Business ( $G$ to $B$ ) agreement. Therefore, Taxpayers are still permitted to use international tax law.

The status of the Double Tax Avoidance Agreement (P3B) or Tax Treaty based on this provision is a lex specialist for domestic law. Therefore, supposing there is a provision in domestic law that contradicts the one in the Tax Treaty, then it is accepted. In accordance with the aforementioned explanation, it was understood that because Indonesia and the UK have a double tax avoidance agreement, the applicable BPT tax rate needs to be $10 \%$, as stipulated in Article 10 paragraph (8).

Besides, supposing there is a suggestion to improve or change the contract contents related to taxation, it has to be carried out through bilateral efforts 
alongside good faith. Furthermore, it is necessary to apply a stabilization clause agreed upon in advance in order to maintain the justice element. Another effort is to improve the article regarding the tax treaty as exemplified by the Indonesian and United States Tax Treaty, which regulates that each party or country needs not to reduce tax payments on BPT (dividends) obtained from the Production Sharing Contract (PSC). However, the Oil and Gas Cooperation contract is a long-term investment that requires large funds and risks.

\section{References}

\section{Books:}

Ali, Chidir. (2005). Badan Hukum. Bandung. Alumni.

Ali, Zainudin. (2015). Metode Penelitian Hukum. Jakarta. Sinar Grafika,

Darrussalam dan Danny Septriadi. (2017). Perjanjian Penghindaran Pajak Berganda Panduan, Interpretasi dan Applikasi. Jakarta. Dimensi Internasional Tax.

Darus Badrulzaman, Mariam. (2015). Hukum Perikatan dalam KUH Perdata Buku Ketiga. Bandung. Citra Aditya Bakti.

Hernoko, Agus Yudha. (2014). Hukum Perjanjian-Asas Proporsional Dalam Kontrak Komersial. Jakarta. Prenadamedia.

Hadjon, Philipus M. dan Tatiek Sri Djatmiati. (2017) Argumentasi Hukum. Jogjakarta. Gadjah Mada University Press.

Hadjon, Philipus M., et.all. (2015). Pengantar Hukum Administrasi Indonesia. Jogjakarta. Gadjah Mada University Press.

Johnston, Daniel. (1994) International Petroleum Fiscal Systems and Production Sharing Contracts. Oklahoma. PennWell Publishing Company.

Khairandy, Ridwan. (2017). Itikad Baik dalam Kontrak. Yogyakarta. FHUII Press.

Soemitro, Rochmat. (1986). Hukum Pajak Internasional Indonesia. Bandung. Eresko.

Sornarajah, M. (2010). The International Law on Foreign Investment. Cambridge. Cambridge University Press.

Subekti. (2010). Pokok Pokok Hukum Perdata. Jakarta. Intermasa.

Surahmat, Rachmanto. (2011). Persetujuan Penghindaran Pajak Berganda (P3B). Jakarta. Salemba Empat. 


\section{Legal Documents:}

The 1945 Constitution of The Republic of Indonesia and the Amendments to the 1945 Constitution - Law Number 5 of 1960 concerning Basic Agrarian Regulations. (State Gazette No. 104 of 1960. Additional State Gazette No. 2043)

- Law Number 8 of 1971 concerning State Oil and Gas Mining Companies. (State Gazette of 1971)

Law Number 21 of 2011 concerning Oil and Natural Gas. (State Gazette Number 136 Year 2001. Additional State Gazette Number 4152)

Law Number 36 of 2008 concerning Income Tax. (State Gazette of The Republic of Indonesia Number 133 of 2008)

Code of Civil law

Indonesian - English Double Taxation Avoidance/Tax Treaty Agreement

Indonesia - United States of America Double Taxation Avoidance/Tax Treaty Agreement

Copy of the Constitutional Court Decision Number 36/PUU-X/2012

Presidential Regulation Number 9 of 2013. State Gazette Number 24 of 2013

Copy of Supreme Court Decision Number 2424/B/PK/Pjk/2020

\section{Dictionary}

Complete Edition of the Legal Dictionary, Dutch-Indonesian-English, Aneka, Semarang, 1977. 